\title{
NILAI-NILAI PENDIDIKAN MULTIKULTURAL DALAM FILM ANIMASI UPIN IPIN EPISODE ESOK HARI RAYA, GONG XI FA CAI, DAN DEEPAVALI
}

\author{
Oleh.
}

\author{
Heri Cahyono \\ Yeni Susanti \\ Universitas Muhammadiyah Metro \\ hericahyono808@gmail.com
}

\begin{abstract}
Multicultural education is education that promotes diversity, difference, and tolerance. The values of multicultural education that are implanted are expected to be a solution to resolve or avoid cases that often occur in Indonesia because of the background of cultural differences in society. The planting of multicultural education values must be applied to the general public, especially to students as early as possible. The values of multicultural education can be done in various ways, one of them is using animated film media, namely the Upin Ipin animated film. children in general will better understand what they often see. Upin Ipin's animated film tomorrow's episodes, gong xi fa cai, and deepavali illustrate how peaceful and peaceful multicultural life. Where in the film illustrates how the reality of multicultural life that lives peacefully even with different cultural backgrounds. In addition, in the animated film Upin Ipin tomorrow's episodes, gong xi fa cai, and deepavali there are multicultural education values namely tolerance, democratic values, help please values, pluralism values, justice values, equality values, equality values, humanism values, and the value puts the dialog first.
\end{abstract}

\section{Keywords: Multicultural Values, Tomorrow's Holiday, Gong Xi Fa Cai, and Deepavali}

\begin{abstract}
Abstrak
Pendidikan multikultural merupakan pendidikan yang mengedepankan keberagaman, perbedaan, dan toleransi. Nilai-nilai pendidikan multikultural yang ditanamkan diharapkan dapat menjadi solusi untuk menyelesaikan atau menghindari adanya kasus yang sering terjadi di Indonesia karena dilatarbelakangi oleh perbedaan kultur yang ada di masyarakat. Penanaman nilai-nilai pendidikan multikultural harus diterapkan kepada masyarakat umunya, terutama kepada peserta didik sejak dini mungkin. Nilai-nilai pendidikan multikultural dapat dilakukan dengan berbagai cara, salah satunya menggunakan media film animasi yaitu film animasi Upin Ipin. anak-anak pada umumnya akan lebih memahami dengan apa yang sering mereka lihat. film
\end{abstract}


animasi Upin Ipin episode esok hari raya, gong xi fa cai, dan deepavali menggambarkan bagaimana kehidupan multikultural yang tentram dan damai. Dimana dalam film tersebut menggambarkan bagaimana realitas kehidupan multikultural yang hidup secara damai meskipun dengan latar belakang kultur yang berbeda. Selain itu, dalam film animasi Upin Ipin episode esok hari raya, gong xi fa cai, dan deepavali terdapat nilai-nilai pendidikan multikultural yaitu nilai toleransi, nilai demokrasi, nilai tolong menolong, nilai pluralisme, nilai keadilan, nilai kesetaraan, nilai humanisme, dan nilai mendahulukan dialog.

\section{Kata Kunci: Nilai Multikultural, Esok Hari Raya, Gong Xi Fa Cai, dan} Deepavali

\section{A. PENDAHULUAN}

Indonesia merupakan salah satu Negara multikultural terbesar di dunia, yang di dalamnya terdapat beraneka etnis, suku, ras, agama, bahasa dan budaya. Tidak hanya itu, Indonesia adalah Negara yang kaya raya.Namun, disinilah merupakan tantangan besar yang dihadapi oleh bangsa dalam mewujudkan kesatuan, persatuan, dan kesejahteraan hidup. Tidak sedikit perlakuan diskriminatif terjadi lantaran adanya perbedaan ras, sosial, maupun bahasa bahkan hal ini juga banyak terjadi tidak hanya pada kalangan orang dewasa tetapi dikalangan anakanak pula. ${ }^{1}$

Konflik karena perbedaan kultul budaya bukanlah suatu hal baru yang sering terjadi di Indonesia, contohnya di Provinsi Lampung. Yang sering terjadi konflik di wilayah Lampung sendiri seperti suku asli Lampung dengan suku Bali, maupun Jawa dengan Bali atau Lampung dengan Jawa. Mengapa ketiga suku tersebut?

1 Budiyanto, Pengantar Pendidikan Iklusif Berbasis Budaya Lokal, (Jakarta: PRENADAMEDIA, 2017). hal. 122 karena mayoritas penduduk Lampung di huni oleh ketiga suku tersebut. ada beberapa konflik yang pernah terjadi di Lampung sepertihalnya konflik Balinuraga Lampung Selatan, Konflik Bumijawa Lampung Timur, Konflik Padang Ratu, Lampung Tengah dan konflik lainnya ${ }^{2}$. Konflik-konflik tersebut bukanlah berakar dari perbedaan kultur, namun karena ada masalah lain yang melibatkan pihak yang berbeda kultur daerah. Dari situlah muncul kesalahan persepsi kultur subyektif dalam menyikapi keragaman identitas etnik, budaya, dan agama dalam kehidupan bermasyarakat. Konflik di atas hanya beberapa dari konflik besar yang pernah terjadi di Provinsi Lampung. Contoh konflik lainnya yang pernah terjadi di Indonesia terutama disepanjang tahun 2018 yaitu seperti penyerangan terhadap ulama di Lamongan, perusakan masjid di Tuban,

${ }^{2}$ Ali $\quad$ S., Heri $\quad$ C., dan Ahmad M.,Gerakan Agama dan Budaya Komunitas Sekelik Sedulur dalam Mencegah Konflik Etnis di Lampung Tengah. (Metro: IAIN 2017) Vol. 02/No. 01, hal. 66 
Ancaman bom di kelenteng Kwan Tee Koen Karawang. ${ }^{3}$

Kasus tersebut hanya sebagian salah satu kasus yang pernah ada di Indonesia karena faktor perbedaan kultur. Mungkin masih banyak kasus bahkan ribuan kasus yang belum pernah kita ketahui. Maka, sudah menjadi keharusan bagi kita semua untuk menjaga persatuan dan kesatuan bangsa ini, dan semua pihak termasuk dari kalangan pendidikan. Pendidikan sangat berperan penting dalam menyelesaikan masalah konflik yang terjadi di lingkungan masyarakat. Setidaknya pendidikan dapat memberikan kesadaran kepada masyarakat bahwa konflik bukanlah suatu hal yang patut untuk dibudayakan. Oleh sebab itu, pendidikan multikultural adalah jawaban atas beberapa problematika yang sering terjadi di masyarakat akibat perbedaan budaya dan agama yang ada.

Seperti yang telah dijelaskan dalam al-Qur'an Surat yang Artinya: Hai manusia, sesungguhnya Kami menciptakan kamu dari seorang laki-laki dan seorang perempuan dan menjadikan kamu berbangsa-bangsa dan bersuku-suku supaya kamu saling kenal mengenal. Sesungguhnya orang yang paling mulia di antara kamu ialah orang yang paling bertaqwa. Sesungguhnya Allah Maha Mengetahui lagi Maha Mengenal. (QS. AlHujarat:13).

${ }^{3}$ Rochmanudin,. Di akses pada tanggal 07 Februari 2019 pukul 06.33

${ }^{4}$ Departemen Agama RI, Mushaf ArRayyan, (Semarang: Raja Publishing, 2011) hal. 517

Ayat di atas menjelaskan bahwasannya Allah SWT menciptakan manusia berbangsa-bangsa dan bersuku-suku, laki-laki dan perempuan tujuannya agar mereka semua dapat saling mengenal dan mudah dikenali. Namun manusia sering mempermasalahkan dan saling mengolok-olok antar sesama karena perbedaan suku, budaya, ras, gender, padahal tujuan Allah SWT menciptakan manusia dengan latar belakang yang berbeda agar mereka semua dapat saling tolong-menolong. Selain itu, manusia seringkali memandang bahwasannya kemuliaan seseorang itu dilihat dari sisi kebangsaan dan kekayaannya. Padahal Allah SWT memandang mulia seorang manusia itu dari tingkat ketaqwaan mereka terhadap-Nya. Jadi kita sebagai seorang muslim patut saling menjaga, menghargai, dan mempererat tali persaudaraan antar seluruh bangsa karena persaudaraan merupakan suatu pilar masyarakat Islam.Menurut pendapat Andersen dan Cusher, pendidikan multikultural dapat diartikan sebagai pendidikan mengenai keberagaman budaya. Kemudian menurut James Bank mendefinisikan pendidikan multiultural sebagai pendidikan untuk people of color ${ }^{5}$ Pendidikan multikultural merupakan pendidikan tentang keberagaman kebudayaan dalam merespon berbagai kultural lingkungan masyarakat tertentu atau bukan dunia secara komprehensif. Pendidikan

\begin{tabular}{lcr}
\hline \multicolumn{1}{c}{ Choirul } & Mahfud, & Pendidikan \\
Multikultural, & (Yogyakarta: & Pustaka \\
Pelajar,2014). hal. 175 &
\end{tabular}


multikultural sebagai upaya untuk melatih dan membangun atau mengeksplorasi perbedaan sebagai anugerah tuhan dan tidak lepas untuk membentuk karakter siswa agar mampu bersikap demokratis, humanis, dan pluralis dalam lingkungan mereka. Pendekatan pendidikan multikultural dilakukan dengan langkah-langkah sebagai berikut: pertama, tidak lagi menyamakan pandangan pendidikan dengan persekolahan, atau pendidikan multikultural dengan program-program sekolah formal. ${ }^{6} \mathrm{Kedua}$, menghindari dari pandangan yang menyamakan sebuah kebudayaan dengan suatu kelompok etnik. Yang artinya tidak lagi mengasosiasikan kebudayaan semata-mata dengan kelompok etnik yang sering terjadi selama ini.Ketiga, mengenai pengembangan kompetensi dalam suatu "kebudayaan baru" perlu interaksi inisiatif dengan orang-orang yang memang telah memiliki kompetensi, maka dapat dilihat dengan jelas bahwasannyaupaya untuk mendukung sekolah-sekolah yang memang terpisah secara etnik merupakan hal yang berlawanan terhadap tujuan pendidikan multikultural. ${ }^{7}$ Keempat, $\quad$ pendidikan multikultural berusaha untuk meningkatkan kompetensi tidak hanya untuk satu kebudayaan akan tetapi untuk meningkatkan kompetensi terhadap beberapa kebudayaan. Kelima, jika memang pendidikan (formal maupun nonformal) meningkatkan kesadaran kompetensi dalam beberapa kebudayaan maka hal

\footnotetext{
${ }^{6}$ Op.cit. hal. 192

${ }^{7}$ Ibid .hal. 193
}

ini akan menghindari dari dikotomi antara pribumi dan nonpribumi.

Pendidikan multikultural dilakukan karena memiliki peran yang sangat penting, diantaranya urgensi pendidikan multikultural terutama di Indonesia ialah: ${ }^{8}$ pertama, sebagai sarana pemecahan konflik. Kedua, supaya siswa tidak tercerabut dari akar budaya. Ketiga, sebagai landasan pengembangan kurikulum nasional. Keempat, menuju masyarakat Indonesia yang multikultural. Dalam hal ini, yang paling terpenting dalam penelitian ini ialah mengenai nilai-nilai pendidikan multikultural itu sendiri. Berdasarkan UNESCO pada bulan Oktober 1994 di Jenawa yang dikutip pada jurnal oleh Salmiwati telah merekomendasikan bahwa dalam pendidikan multikultural setidaknya harus memuat beberapa pesan. ${ }^{9}$ Yang pertama, pendidikan hendaknya mengembangkan kemampuan untuk mengakui dan menerima nilai-nilai yang ada pada kebhinekaan pribadi, jenis kelamin, masyarakat dan budaya serta mengembangkan kemampuan untuk berkomunikasi. Kedua, pendidikan hendaknya meneguhkan jati diri dan mendorong gagasan dan penyelesaian-penyelesaian yang memperkokoh perdamaian, persaudaraan serta solidaritas antara pribadi dan masyarakat. Ketiga, pendidikan hendaknya meningkatkan kemampuan menyelesaikan konflik

${ }^{8}$ Ibid. h. 216

${ }^{9}$ Salmiwati. Urgensi Pendidikan Agama Islam Dalam Pengembangan Nilai-Nilai Multikultural. Jurnal Al-Ta'lim,2013. Vol. 20. No. 1. hal. 338 
secara damai tanpa kekerasan. Dari rekomendasi diatas, maka didapatkan beberapa nilai multikultural yang ada pada pendidikan, yaitu sebagai berikut:nilai toleransi, nilai demokrasi, nilai kesetaraan, nilai keadilan, nilai pluralisme, nilai pluralisme, nilai humanisme, nilai tolong menolong, nilai inklusi, dan nilai mendahulukan dialog.

\section{Sehingga,} pendidikan

multikultural dapat di rumuskan sebagai wujud kesadaran tentang keanekaragaman kultural, hak-hak asasi manusia serta pengurangan atau penghapusan berbagai jenis prasangka untuk membangun suatu kehidupan masyarakat yang adil dan maju. Pendidikan multikultural merupakan suatu aternatif melalui penerapan strategi dan konsep pendidikan yang berbasis pemanfaatan keberagaman yang ada di masyarakat khususnya yang ada pada peserta didik seperti keberagaman etnis, budaya, bahasa, agama, status sosial, gender, kemampuan, umur dan ras. Untuk mewujudkan pendidikan multikultural sebagai problem solving dalam menyelesaikan konflik yang terjadi di masyarakat terutama dalam lingkungan peserta didik, maka seharusnya segala daya dan upaya dilakukan oleh para pelaku pendidikan termasuk dalam pemilihan media pembelajaran. Karena media adalah bagian yang tidak terpisahkan dari proses belajar mengajar demi tercapainya tujuan pendidikan. ${ }^{10}$ Ada beberapa macam

\footnotetext{
${ }^{10}$ Azhar Arsyad, Media Pembelajaran, (Jakarta, PT Raja Grafindo Persada, 2014), hal 2
}

media yang dapat di gunakan dalam sebuah pembelajaran, media pembelajaran berbasis audio visual yaitu salah satunya adalah film. Film dimasukkan sebagai media belajar karena isi dari film yang memuat pesan-pesan moral serta kisah-kisah yang termuat merupakan kisah ringan dan menarik. Film mampu menarik dan memikat perhatian orang-orang tanpa memakan waktu lama. Karena dalam kehidupan sehari-hari komunikasi bersifat audio sangat mendominasi kehidupan manusia. Film merupakan bagian dari produk budaya yang isinya memuat nilai-nilai budaya, sehingga film juga menjadi media efektif untuk menanamkan nilai budaya atau pendidikan, baik kepada peserta didik maupun masyarakat umum. Sifatnya yang audio-visual membuat informasi yang menyenangkan, menarik, jelas, dan mudah dimengerti oleh penontonnya bahkan anak kecil sekalipun.

Film bukan hanya suatu hasil rekaman dari suatu adegan cerita sandiwara antara tokoh-tokoh yang merupakan manusia saja, tetapi juga segala sesuatu yang merupakan hasil dari rekaman benda mati yang digerakkan dan yang dapat diputar ulang melalui proses-proses tertentu. Film yang menggunakan benda yang mati atau tidak dapat bergerak dengan sendirinya yang kemudian digerakkan oleh manusia dan disusun kemudian direkam sehingga menimbulkan ilusi seakan-akan benda tersebut hidup disebut dengan film animasi.Mengenai fenomena sosial yang terjadi saat ini karena terkait multikultural, ada 
banyak berbagaima macam media film yang berkaitan tentang pendidikan multikultural. Salah satu film yang mengajarkan tentang bagaimana pendidikan multikultural yaitu terdapat dalam film animasi Upin dan Ipin.Film Upin Ipin merupakan sebuah film animasi yang dirilis pada tanggal 14 September 2007 di Malaysia yang disiarkan di TV9 yang di produksi oleh Les' Compaque. Film animasi Upin Ipin ini awal diputar bertujuan untuk memberikan pendidikan kepada anakanak agar dapat menghayati dan paham akan pentingnya bulan suci Ramadhan. Film animasi ini di buat oleh Mohd Nizam Abdul Razak, Mohd Sofwan Abdul Karim dan Usamah Zaid. Ketiganya merupakan para alumni dari Multimedia University Malaysia. Mereka awalnya bekerja pada sebuah organisasi animasi yang sebelumnya bertemu dengan $\mathrm{H}$. Burhanuddin Radzi dan istrinya $\mathrm{Hj}$. Ainon Arif pada tahun 2005 yang dulunya mereka hanya sebagai pedagang minyak serta gas di Negaranya, dan kini mereka bergabung membuka organisasi Les' Compaque. 11 adapun para pemain film animasi ini ialah Upin dan Ipin (Nur Fathiah), Kak Ros (Ida Shareera), Opah (Hj. Ainon Ariff), Fizi (Ida Rahayu Yusoff), Ehsan (Mohd Syahmid Abdul Hamid), Rajoo (Kannan), Mei Mei (Ee Jean), Mail(Hasrul), Jarjit Singh (Mohd Shafiq), Cikgu Yasmin (PN Jasmin Ally), Susanti (Andhika), Tok Dalang (Abu Shafian Abdul Hamid), Badrol,

\footnotetext{
${ }^{11}$ Alif. Sinopsis Film Upin dan Ipin. 2008.http ://acan-on-skyes.blogspots.com . Diakses pada tanggal 04 Maret 2019 pukul 21.00
}

Dzul dan Ijat, Devi (Maheswary Mohan), Muthu (Mohd Shafiq), Salleh(Ros Hasrol Ahmad), Ah Tong (Mohd Shafiq), dan Azzarudin.

Film animasi Upin dan Ipin merupakan sebuah film yang menarik untuk di tonton khususnya untuk anakanak usia dini dan film animasi ini dapat dijadikan rujukan rujukan dalam menjalani kehidupan yang multikultural. Pendidikan Anak Usia Dini saat ini belum sepenuhnya memperhatikan secara serius bagaimana penerapan pendidikan karakter, terlebih terkait dengan pendidikan budaya lokal seperti yang tertuang pada fungsi dan tujuan pendidikan

Nasional, yaitu'Mewujudkan masyarakat berakhlak mulia, bermoral, beretika, dan berbudaya dan beradab berdasarkan falsafah Pancasila". ${ }^{12}$ Maka dari itu melalui film animasi ini tidak hanya memberikan pelajaran mengenai moral saja, tetapi memberikan pembelajaran bagaimana berinteraksi dalam satu lingkungan dengan kultur yang berbeda.

Masalah kultur yang terjadi dapat dilihat jelas dari alur cerita yang ada dalam film animasi ini yang berkisar pada interaksi anak-anak yang ada dalam film animasi tersebut yang mengandung pendidikan serta unsur Islam seperti menghormati sesama kawan yang berbeda kaum dan agama sehingga watak-wataknya bukan saja

\footnotetext{
${ }^{12}$ Kemendikbud Balai Pengembangan Pendidikan Anak Usia Dini Nonformal dan Informal (BPPAUDNI) Regional III Makassar, Model Pendidikan Karakter Berbasis Kearifan Lokal Pada Anak Usia Dini. (Makassar:2012) .hal. 3
} 
terdiri dari orang Melayu, Cina dan Tamil, bahkan juga orang Indonesia. ${ }^{13}$ Namun, perbedaan budaya bukan penghalang untuk menjalin tali interaksi sosial dalam film tersebut. Bahkan semuanya berinteraksi dan bersosialisasi dengan baik. Dengan itu, film animasi Upin dan Ipinsangat sesuai untuk pendidikan dalam menggambarkan bagaimana menanamkan nilai-nilai multikultural kepada peserta didik. Sepertihalnya mendidik anak agar memiiki sifat menghargai perbedaan, menghargai keragaman, toleransi, demokrasi, berbuat adil, humanis, terbuka dan pluralis. Ketika anak terbiasa melihat tontonan yang memang layak untuk anak-anak tonton, maka kemungkinan besar anak-anak akan menirukan apa yang mereka liat dan dengar. ${ }^{14}$ Karena perlu penanaman pendidikan multikultural sejak dini sehingga kedepannya nanti anak-anak mempunyai sikap saling menghargai dan menghormati dalam setiap perbedaan dalam lingkungan sekitar. Dengan film Upin dan Ipin inilah salah satu cara memberikan edukasi terhadap anak-anak dan memberikan manfaat terhadap pendidik bagaimana memilik media yang baik dan tepat. Sehingga peneliti tertarik untuk melakukan penelitian terkait dengan nilai-nilai pendidikan multikultural dalam film animasi upin ipinepisode esok hari raya, gong xi fa cai, dan deepavali ".

\section{B. METODE PENELITIAN}

Penelitian ini juga termasuk penelitian deskriptif kualitatif yang berusaha mengungkapkan suatu masalah atau peristiwa sebagaimana adanya. Hasil penelitian ditekankan secara obyektif tentang keadaan yang sebenarnya pada obyek yang diteliti. Akan tetapi untuk mendapatkan manfaat yang lebih luas, perlu disertai interpretasi-interpretasi yang kuat. Jenis pendekatan dalam penelitian ini adalah pendekatan semiotik kultural. Semiotik kultural yaitu menelaah sistem tanda dalam bentuk kebudayaan masyarakat tertentu. ${ }^{15}$ Sumber data yang digunakan dalam penelitian ini yaitu sebagai berikut: pertama, sumber data primer yang merupakan sumber asli baik dalam bentuk dokumen ataupun peninggalan lainnya. Data primer dalam penelitian ini yaitu veideo film animasi Upin dan Ipin episode esok hari raya, gong xi fa cai, dan deepavali. Kedua, yaitu sumber dataskunder yang merupakan sumberdata yang secara tidak langsung memberikan data kepada pengumpul data, seperti lewat orang lain atau lewat dokumen. Dalam penelitian ini sumber data skunder yang digunakan ialah berbagai media yang membahas film animasi Upin dan Ipin seperti televisi, majalah, dan internet.

\footnotetext{
${ }^{13}$ Febri Aishiteru, Sinopsis Film. Di akses tanggal 07 November 2018 pukul 21.36

14 Mansur, Pendidikan Anak Usia Dini dalam Islam, (Yogyakarta: Pustaka Pelajar, 2014), hal. 174
}

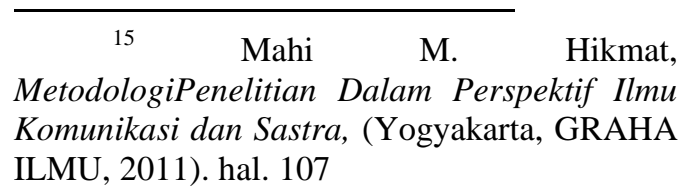




\section{PEMBAHASAN}

Pendidikan multikultural sangat penting diterapkan dalam suatu pendidikan di Indonesia, mengingat bahwasannya Indonesia merupakan salah satu negara multikultural yang sangat besar. Dengan keanekaragaman tersebut Indonesia sendiri mendapatkan tantangan yang cukup besar untuk mewujudkan bangsa persatuan, kesatuan, dan kesejahteraan hidup. Tidak sedikit konflik pun banyak bermunculan akibat dari perbedaan kultur, budaya, ras, bahasa, dan agama. Maka diharapkan pendidikan multikultural dapat menjadi solusi untuk menyelesaikan konflik yang terjadi karena latarbekang kultur yang berbeda.

Pendidikan multikultural memandang manusia tidak dapat terlepas dari akar budaya dan mengakui adanya keberagaman etnik dan budaya masyarakat suatu bangsa. Sangat penting untuk menanamkan pendidikan multikultural sejak dini mungkin. Tujuan pendidikan multikultural yaitu untuk membantu semua siswa khususnya anak usia dini agar memperoleh pengetahuan, sikap dan keterampilan yang diperoleh dalam menjalankan peran-peran seefektif mungkin pada masyarakat yang pluralis, serta diperlukan untuk berinteraksi,negoisasi dan komunikasi dan komunikasi dengan warga kelompok lain agar tercipta suatu tatanan masyarakat yang bermoral yang berjalan untuk kebaikan bersama serta membutuhkan sikap toleransi dan saling menghargai dalam setiap perbedaan.
Di harapkan dengan adanya pendidikan multikultural ini menjadi sebuah problem solving untuk mengatasi konflik yang ada. Namun tidak mudah untuk mewujudnya pendidikan multikultural sebagai sebuah problem solving. Segala daya dan upaya harus dilakukan dalam proses pendidikan terutama yang paling mendukung yaitu media pendidikan. Karena keberhasilan pendidikan tidak terlepas dari media yang baik dan benar. Ada banyak macam media pembelajaran yang dapat digunakan, mulai dari media pembelajaran visual, audio, dan audio visual. Media pembelajaran sangat penting digunakan karena untuk menunjang pembelajaran agar lebih baik. Salah satu media yang digunakan dalam sebuah pembelajaran khususnya dalam sistem pendidikan multikultural yaitu dengan menggunakan media audio visual yaitu melalui film animasi Upin Ipin.Film animasi Upin Ipin bukan hanya sekedar tontonan saja, namun memiliki unsur pendidikan yang tidak hanya sedikit tersirat dalam setiap alur ceritanya. Film animasi Upin Ipin banyak mengandung unsur pendidikan seperti pendidikan karakter, ibadah, dan pendidikan multikultural.Masalah kultur yang terjadi dapat dilihat dalam alur cerita yang ada dalam film animasi ini yang berkisar pada interaksi anak-anak yang ada dalam film tersebut mengandung unsur-unsur pendidikan. Perbedaan budaya bukanlah menjadi suatu penghalang untuk menjalin tali interaksi sosial dalam film tersebut. Dengan menonton film ini, anak-anak 
yang menontonnya khususnya anak usia dini dapat menerapkan hal yang ditangkap dalam kehidupan sehari-hari dengan lingkungan kultur yang berbeda. Dengan menggunakan pendekatan semiotik kultural penulis dapat menelaah tanda dalam bentuk kebudayaan masyarakat tertentu dalam film animasi Upin Ipin episode esok hari raya, gong xi fa cai, dan deepavali. Kemudian penulis melakukan pengumpulan data yaitu dengan menggunakan tehnik dokumentasi yaitu dengan cara memperoleh langsung data melalui film animasi Upin Ipin. Setelah penulis melakukan pengumpulan data, penulis melakukan analisis data yaitu dengan menggunakan tehnik content analysis yaitu penelitian yang dilakukan terhadap pesan-pesan menggunakan metode ilmiah dan tidak terbatas pada jenis-jenis variabel yang dapat diukur atau konteks tempat pesan-pesan diciptakan atau disajikan. Setelah melakukan analisis data, maka penulis menemukan suatu nilai yang terkandung dalam film animasi Upin Ipin yaitu terdapat nilai pendidikan multikultural yaitu terkandung dalam episode esok hari raya, gong xi fa cai, dan deepavali. Nilai-nilai ini diharapkan dapat dipahami dan diterapkan oleh para penontonnya khususnya anak usia dini pada kehidupan sehari-hari terlebih dalam kehidupan masyarakat yang multikultural.

Nilai-nilai pendidikan multikultural yang terkandung dalam film animasi Upin Ipin episode esok hari raya, gong xi fa cai, dan deepavali diantaranya ialah:

1. Toleransi

Toleransi merupakan suatu sikap dan rasa untuk saling menghargai dan menghormati antara satu dengan yang lain dalam suatu kehidupan bermasyarakat baik dalam segi agama, suku, sikap, pendapat, dan etnis, menjungjung tinggi persatuan dan kesatuan demi terwujudnya kehidupan bangsa dan negara yang damai. Adegan yang mengandung nilai toleransi terkandung pada episode esok hari raya yaitu ketika Mei Mei memberikan nasihat terhadap Upin Ipin yang pada saat itu tengah selesai bermain. Berikut potongan dialognya

Upin : huh....penatnye.

Ipin : hauslah pulee.

Rajoo: sebab kau orang menang,,mari saya blanja kau orang minum.

Upin Ipin : baik boss.

Mei Mei: ehhh..kamu bedua

kan puasa.

Upin Ipin : puasa...puasa.

Rajoo: hallah tak ape, orang tak tahu.

Upin Ipin : betul...betul...betul

Mei Mei: tak boleh, you puya Tuhan tahu owh. Nanti ha, you punya Tuhan marah. Mana boleh main-main. 


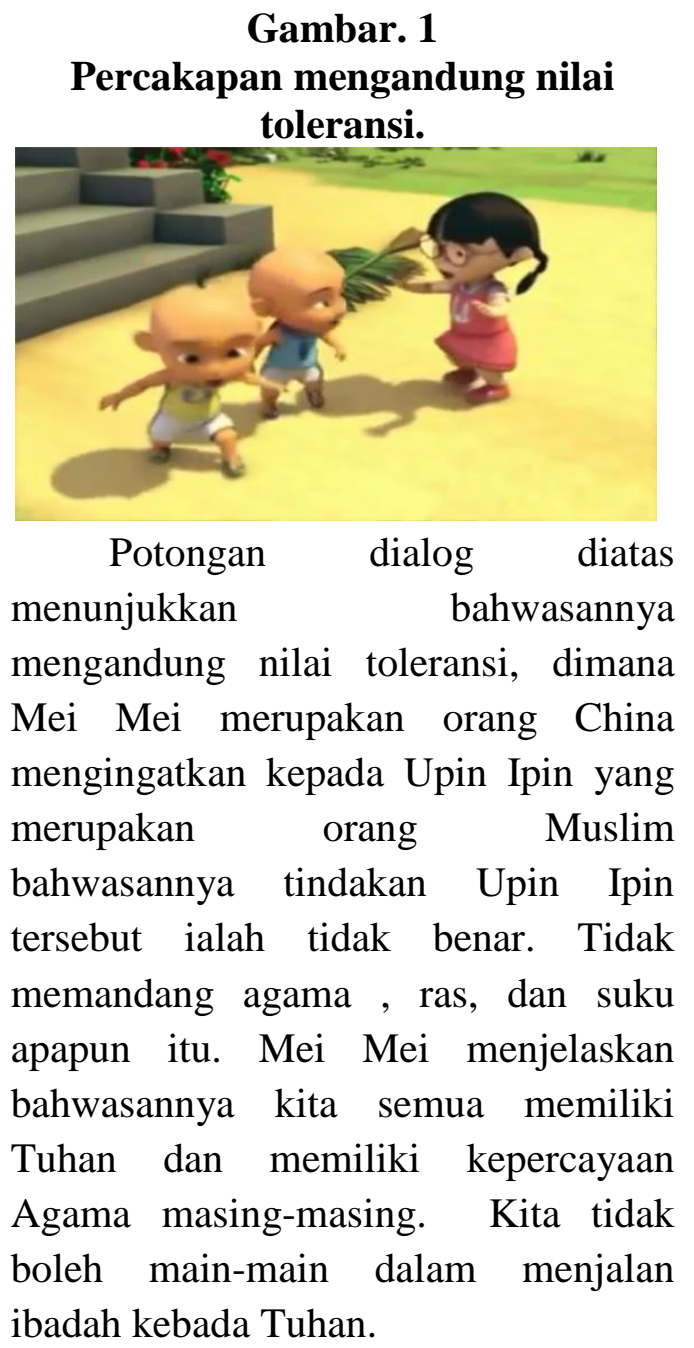

2. Demokrasi

Demokrasi menjunjung tinggi persamaan hak setiap individu, demokrasi memberikan hak yang sama tanpa membeda-bedakan satu sama lain dan tanpa harus melihat latar belakang baik dari segi budaya, ras, suku, agama, gender, etnis, serta tidak diperbolehkan adanya suatu penindasan baik bersifat perorangan ataupun kelompok.

Nilai demokrasi yang terdkandung dalam film animasi Upin Ipin terletak pada episode gong $x i f a$ cai pada saat Upin Ipin menerima panggilan telefon dari Ehsan bahwasaanya Ehsan ketika pergi ke rumah Mei Mei nanti untuk merayakan gong xi fa cai dia akan memakai baju raya Cina. Upin Ipin pun langsung bertanya pada Opahnya perihal apakah harus memakai baju raya Cina untuk pergi ke rumah Mei Mei.Berikut potongan dialognya:

Upin dan Ipin : kalau tak pakai, tak boleh pergi ke rumah Mei Mei kah?

Opah : siapa cakap? Pakai saje ape-ape. Asalkan sopan.

Gambar. 2

Percakapan mengandung nilai demokrasi

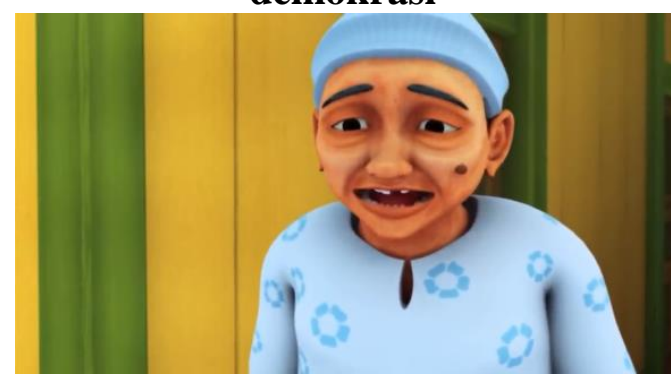

Dialog tersebut mencerminkan bahwasannya semua orang berhak datang ke rumah Mei-Mei untuk ikut serta merayakan hari raya Cina tanpa harus memakai pakaian rakyat Cina. Semua orang memiliki hak yang sama tanpa harus memandang status sosial dan dari latar belakang apapun itu.

3. Tolong menolong

Sikap saling tolong menolong merupakan suatu sikap tulang punggung dalam hidup bermasyarakat. Maka dari itu kita harus memberikan contoh yang baik mengenai bagaimana sikap saling tolong menolong agar generasi selanjutnya dapat melanjutkan sikap kerja sama sosial yang telah dibangun. Karena memang kita semua memang bersaudara, dan sudah sepatutnya kita harus saling tolong menolong. Sikap saling tolong 
menolong terdapat pula dalam film animasi Upin Ipin yang terkandung dalam episode deepavali. Adegan yang pertama terletak ketika Upin Ipin yang membantu Muthu mengangkat barangbarangnya yang jatuh berantakan karena kereta yang mereka naiki rodanya patah akibat lewat jalan bebatuan. Berikut potongan dialognya:

Upin dan Ipin : kenapa uncle?

Muthu : ini roda sudah patah.

Upin dan Ipin: habis thu macem mana ini?

Muthu : hhhhhh, cepat angkat semua barang.

Gambar. 3

Percakapan mengandung nilai tolong menolong.

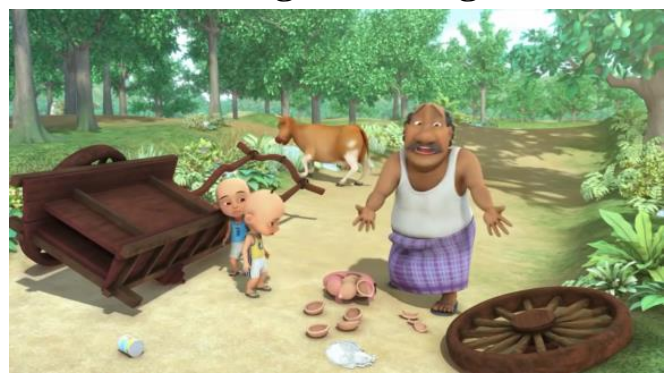

Upin dan Ipin pun membantu Muthu mengangkat barang-barang yang jatuh berantakan. Adegan tersebut mencerminkan bahwasannya kita sebagai manusia mempunyai rasa empati dan ikut merasakan apa yang orang lain rasakan, maka kita pun tergerak untuk menolong orang lain ketika sedang mengalami musibah. Dalam hal ini penonton khususnya anak-anak diajarkan untuk berbuat saling tolong menolong tanpa harus melihat latarbelakang siapa yang kita tolong.

4. Pluralisme

Pluralisme merupakan suatu sikap saling menghormati terhadap perbedaan yang ada dimasyarakat baik dari segi fisik, adat, suku, budaya dan agama. Film animasi Upin Ipin telah mengajarkan kita bagaimana bersikap pluralisme. Dimana adegan yang mencerminkan sikap pluralisme yaitu yang pertama terletak pada episode gong xi fa cai ketika Opah menjelaskan kepada Upin Ipin makna hari raya Cina bagi masyarakat Cina. Berikut potongan dialognya:

Upin : opah,,Mei Mei kate dia nak balek kampung. Ada makan besak. Ipin : Iya opah.

Opah : memang...malem tahun baru Cina semua ahli keluarga akan berkumpul dirumah orang tua mereka untuk makan besak. Makan besak nih besak maknanye pada orang Cina. Ia merapatkan hubungan antara ahli keluarga yang jarang-jarang dapat berjumpa.

Gambar. 4

Percakapan Mengandung Nilai Pluralisme.

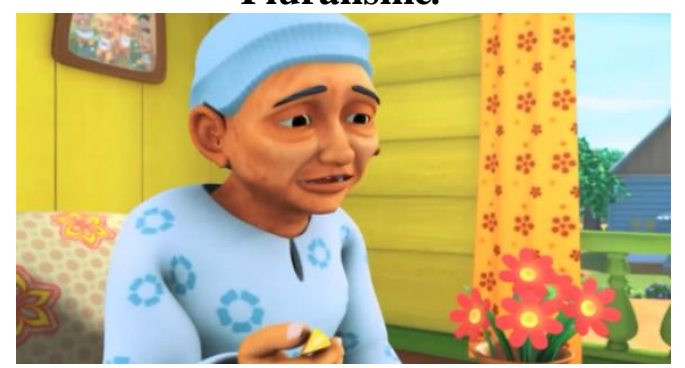

5. Keadilan

Keadilan diartikan sebagai menempatkan sesuatu pada tempatnya atau bisa juga diartikan sebagai menempatkan sesuatu sesuai dengan aturannya. Keadilan memberikan hak yang sama terhadap suatu individu ataupun kelompok dengan status yang sama tanpa melihat kondisi latarbelakang yang berbeda baik dari 
segi bidaya, etnis, agama, ras, suku, dan lainnya.

Keadilan dalam film animasi Upin Ipin terdapat dalam episode gong xi fa cai dimana Mei Mei membagikan jeruk kepada semua temannya dengan sama tanpa membeda-bedakan suku, budaya, ras, maupun agama. Berikut ini potongan dialognya:

Mei Mei : nah ambilah,mama saya suruh kasih kawan-kawan makan. Ehsan : banyaknya limau.

Mei Mei : ambil, banyak-banyak pun tak apa.

\section{Gambar. 5}

Percakapan Mengandung Nilai Keadilan.

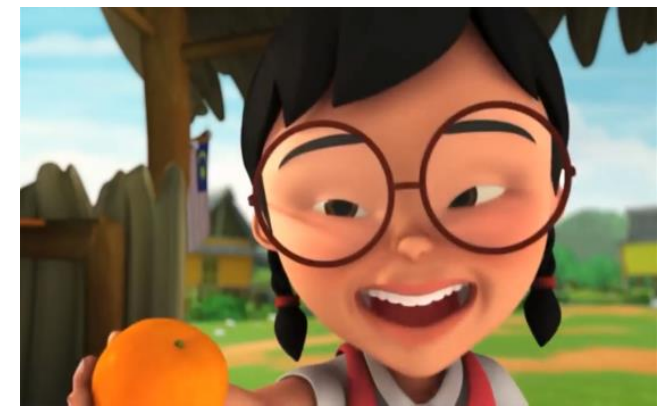

Dialog diatas menggambarkan bahwasannya Mei Mei yang akan merayakan gong xi fa cai tidak hanya membagikan jeruk kepada orang yang satu keyakinan sama dia, namun ia memberikan kepada semua temantemannya yang memang berbeda keyakinan dengan Mei Mei. Adegan tersebut mengajarkan kepada para penonton khususnya terhadap anakanak tentang bagaimana sikap adil terhadap sesama tanpa harus memandang latar belakang hehidupan masing-masing baik dari segi ras, suku, agama, budaya, maupun bahasa.

\section{Kesetaraan}

Kesetaraan atau kesederajatan memiliki arti tingkatan yang sama atau kedudukan yang sama, tidak lebih tinggi ataupun lebih rendah.Dalam film animasi Upin Ipin terdapat nilai kesetaraan dimana terlihat ketika Opa menyuruh Upin Ipin maen ke tempat ucle Ah Tong yang merayakan gong xi fa cai sendiri di rumahnya. Berikut ini potongan dialognya:

Opa : kau berdua tak pergi beraye? Upin : tunggu Mei Mei balek. Opa : kenape tak pergi rumah uncle Ah Tong? Kasihan dia seorang-seorang.

Upin : tak nak lah, uncle tak ajak pun.

Ipin : ho'oh.

Opa : pergi aje lah.

Gambar. 6

Percakapan mengandung nilai kesetaraan.

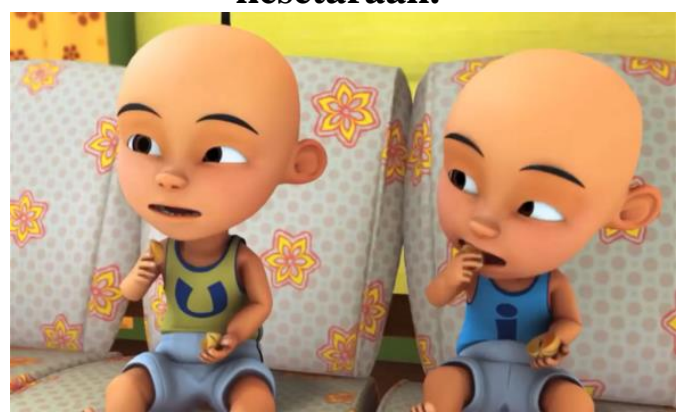

Percakapan diatas menggambarkan bahwasannya semua orang mempunyai hak yang sama ataupun setara tanpa harus memandang tua ataupun muda. Dialog diatas Upin Ipin diajarkan untuk bersikap sama terhadap uncle Ah Tong meskipun ia lebih tua. Kesetaraan mengajarkan untuk bersikap yang adil dalam artian menunjukkan sikap yang sama kedudukannya. Dengan demikian anakanak yang menonton adegan tersebut diharapkan dapat mengambil nilai kesetaraan dalam film animasi tersebut 
kemudian dapat menerapkannya dalam kehidupan sehari-hari. Tidak ada kedudukan yang lebih tinggi maupun lebih rendah, semua memiliki tingkatan kedudukan yang sama.

7. Humanisme

Humanisme sering kita artikan bahwasannya humanisme merupakan suatu pendidikan dengan konsep memanusiakan manusia. Humanisme lebih menekankan kepada harkat, peran, serta tanggungjawab setiap manusia. Setiap manusia memiliki kedudukan yang istemewa dan kemampuan lebih dari mahluk lainnya. humanisme sangat berkaitan dengan kegiatan dalam kehidupan bermasyarakat seperti humanisme yang berkaitan dengan dunia pendidikan.

Nilai humanisme terdapat dalam film animasi Upin Ipin terletak pada episode gong xi fa cai yaitu pada saat Upin Ipin ditanya oleh Opa mengapa mereka tidak pergi untuk berhari raya, namun Upin Ipin menjawab tidak karena Mei Mei belum ada di rumah. Kemudian opa menasihati untuk pergi ke rumah uncle Ah Tong yang sendirian dirumahnya. Berikut ini potongan dialognya: beraye?

Opa : kau berdua tak pergi

Upin : tunggu Mei Mei balek.

Opa : kenape tak pergi rumah uncle Ah Tong? Kasihan dia seorangseorang. pun.

Upin : tak nak lah, uncle tak ajak

Ipin : ho'oh.

Opa : pergi aje lah.

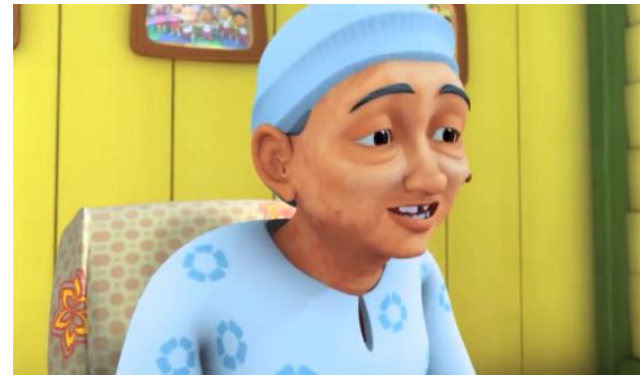

Gambar 10.

Percakapan antara Upin Ipin dan Opa yang mengandung nilai humanisme.

Percakapan antara Upin Ipin dan Opa di atas merupakan suatu pelajaran dimana kita tidak boleh membedabedakan satu sama lain, semua orang memiliki hak yang sama. Dalam dialog di atas secara tidak langsung Opa mencoba menjelaskan kepada Upin Ipin bahwasannya mereka tidak hanya berkunjung ke tempat teman mereka. Namun berkunjunglah pula kepada orang yang lebih tua dari pada mereka. intinya tidak boleh membeda-bedakan satu sama lain, tidak boleh memandang tua ataupun muda.

8. Mendahulukan dialog

Dengan dialog maka akan memudahkan untuk saling memahami tentang suatu hal yang berbeda yang dimiliki oleh orang lain ataupun orang lain tanpa merugikan masing-masing pihak. Maka dengan mendahulukan dialog akan menghasilkan suatu hubungan yang erat, saling memahami, saling tolong menolong, dan lain sebagainya.

Nilai mendahulukan dialog terdapat pada film animasi Upin Ipin episode deepavali yaitu ketika Upin Ipin bercerita kepada Opa tentang masalah yang dialami Muthu yang tidak dapat merayakan pesta cahaya. 
Kemudian Opa menjelaskan bagaimana makna hari deepavali bagi umat Hindu. Upin Ipin pun esok paginya berniat untuk membantu Muthu untuk mempersiapkan menyambut hari deepavali. Dengan Upin Ipin mendahulukan dialog bercerita tentang masalah Muthu tersebut, maka mereka pun dapat memahami makna deepavali bagi umat Hindu dan muncul sikap saling tolong menolong terhadap sesama.

\section{KESIMPULAN}

Pendidikan

multikultural merupakan suatu pendidikan yang mengedepankan perbedaan, kesetaraan, keragaman, toleransi dan demokrasi. Pendidikan multikultural yang ada di harapkan dapat menjadi salah satu solusi dalam menangani konflik yang sering terjadi di masyarakat karena kurangnya sikap toleransi terhadap setiap perbedaan yang ada dalam masyarakat baik dari segi kultur, budaya, ras, dan agama. Maka perlu adanya penanaman nilai-nilai pendidikan multikultural sejak dini mungkin terhadap peserta didik khususnya anak-anak. penerapan pendidikan multikultural dapat dilakukan melalui media film, salah satu contohnya yaitu film animasi Upin Ipin karena melihat film animasi ini menjadi tontonan setiap hari bagi anakanak usia dini. Film animasi ini tidak hanya sekedar tontonan atau bukan hanya sekedar tayangan hiburan semata, tetapi banyak mengandung nilai-nilai edukasi yang terkandung dalam film animasi tersebut.diharapkan anak-anak ketika menonton film animasi ini tidak hanya sekedar terhibur karena melihat setiap adegannya, tetapi dapat mengambil pelajaran yang ada dalam film tersebut salah satunya mengenai pendidikan multikultural yang ada dalam film animasi Upin Ipin.

Berdasarkan penelitian yang telah dilakukan dalam film animasi Upin Ipin episode esok hari raya, gong xi fa cai, dan deepavali bahwasannya dapat di simpulkan bahwasannya film animasi Upin Ipin episode esok hari raya, gong xi fa cai, dan deepavali bukan hanya sekedar serial televesi hiburan semata, namun mengandung nilai-nilai edukasi yang tersirat terutama dalam episode esok hari raya, gong xi fa cai, dan deepavali yaitu mengandung nilai-nilai pendidikan multikultural.Dalam adegan yang telah diperankan dalam ketiga episode menggambarkan bagaimana masyarakat di dalam film tersebut dapat hidup dengan damai meskipun dalam masyarakat tersebut terdiri dari berbagai kultur budaya dan agama. Nilai-nilai pendidikan multikultural yang terdapat dalam film animasi Upin Ipin episode esok hari raya, gong xi fa cai, dan deepavali yaitu: Pertama yaitu nilai toleransi, kedua yaitu nilai demokrasi, ketiga yaitu nilai tolong menolong, keempat nilai pluralisme, kelima nilai keadilan, keenam nilai kesetaraan, ketujuh nilai humanisme, dan kedelapan nilai mendahulukan dialog. 


\section{DAFTAR PUSTAKA}

Ali S., Heri C., dan Ahmad M.,Gerakan Agama dan Budaya Komunitas Sekelik Sedulur dalam Mencegah Konflik Etnis di Lampung Tengah. (Metro: IAIN 2017) Vol. 02/No. 01

Alif. Sinopsis Film Upin dan Ipin. 2008.http ://acan-onskyes.blogspots.com . Diakses pada tanggal 04 Maret 2019 pukul 21.00

Azhar Arsyad, Media Pembelajaran, Jakarta, PT Raja Grafindo Persada, 2014

Budiyanto, Pengantar Pendidikan Iklusif Berbasis Budaya Lokal, Jakarta: PRENADAMEDIA, 2017

Choirul Mahfud, Pendidikan Multikultural, Yogyakarta: Pustaka Pelajar,2014

Departemen Agama RI, Mushaf ArRayyan, Semarang: Raja Publishing, 2011

Febri Aishiteru, Sinopsis Film. Di akses tanggal 07 November 2018 pukul 21.36

Kemendikbud Balai Pengembangan Pendidikan Anak Usia Dini Nonformal dan Informal (BPPAUDNI) Regional III Makassar, Model Pendidikan Karakter Berbasis Kearifan Lokal Pada Anak Usia Dini. Makassar:2012

Mahi M. Hikmat, MetodologiPenelitian Dalam Perspektif Ilmu Komunikasi dan Sastra, GRAHA ILMU, 2011

Mansur, Pendidikan Anak Usia Dini dalam Islam, Yogyakarta: Pustaka Pelajar, 2014

Rochmanudin,. Di akses pada tanggal 07 Februari 2019 pukul 06.33

Salmiwati. Urgensi Pendidikan Agama Islam Dalam Pengembangan
Nilai-Nilai Multikultural. Jurnal Al-Ta'lim,2013. Vol. 20. No. 1. h. 338 